\title{
Oestrous cycles and the breeding season of the Père David's deer hind (Elaphurus davidianus)
}

\author{
J. D. Curlewis*, A. S. I. Loudon and A. P. M. Coleman \\ M.R.C./A.F.R.C. Comparative Physiology Research Group, The Institute of Zoology, \\ The Zoological Society of London, Regent's Park, London NWI 4RY, U.K.
}

\begin{abstract}
Summary. Reproductive cycles were studied in a group of tame Père David's deer hinds. The non-pregnant hind is seasonally polyoestrous and, in animals studied over 2 years, the breeding season began in early August ( 2 August $\pm 3 \cdot 3$ days; s.e.m., $N=9$ ) and ended in mid-December ( 18 December $\pm 5 \cdot 7$ days; $N=8$ ) and early January (6 January \pm 3.2 days; $N=11$ ) in consecutive years. During the anoestrous period, plasma progesterone concentrations were low $(0.2 \pm 0.01 \mathrm{ng} / \mathrm{ml})$ or non-detectable. There was a small, transient increase in progesterone values before the onset of the first cycle of the breeding season. In daily samples taken during an oestrous cycle in which hinds were mated by a marked vasectomized stag, progesterone concentrations remained low $(<0.5 \mathrm{ng} / \mathrm{ml})$ for a period of about 6 days around the time of oestrus, showed a significant increase above oestrous levels by Day 4 (Day $0=$ day of oestrus) and then continued to increase for $18 \pm 2.8$ days to reach mean maximum luteal levels of $3.5 \pm 0.6 \mathrm{ng} / \mathrm{ml}$. The plasma progesterone profiles from a number of animals indicated that marking of the hinds by the vasectomized stag did not occur at each ovulation during the breeding season and therefore an estimate of the cycle length could not be determined by this method. In the following year, detection of oestrus in 5 hinds was based on behavioural observations made in the absence of the stag. A total of 19 oestrous cycles with a mean length of $19 \cdot 5 \pm 0.6$ days was observed. However, on other occasions, the length of the luteal phase, as assessed by plasma progesterone concentrations, showed considerable variation.

During the breeding season, experiments were conducted to investigate synchronization of oestrus with exogenous progestagens. Oestrus occurred $32-90 \mathrm{~h}$ after progestagen removal. The changes in plasma progesterone concentrations which followed oestrus were similar to those seen after natural oestrus.
\end{abstract}

Keywords: deer; oestrous cycles; progesterone; behaviour

\section{Introduction}

The Père David's deer (mi lu; Elaphurus davidianus) originated from China but during the current century became extinct in the wild. However, captive populations had been established in European zoos and from these animals the species has survived to the present day. In recent times there has been a growing interest in the use of this species in the deer farming industry. Père David's deer is a seasonal breeder with $75 \%$ of births occurring in April (Kirkwood et al., 1987) which is about 2 months earlier than in red deer (Adam et al., 1985). Spring calving would be advantageous in many agricultural systems and, in view of its large body size and rapid growth rate when compared with red deer (unpublished results), the Père David's deer may offer advantages over species currently farmed. As there is no published information on the reproductive physiology of the Père David's deer, the present study of non-pregnant animals was undertaken. The aims of this study

\footnotetext{
*Present address: MRC Reproductive Biology Unit, Centre for Reproductive Biology, 37 Chalmers Street, Edinburgh EH3 9EW, U.K.
} 
were to describe the oestrous cycle (natural and synchronized) in terms of peripheral progesterone concentrations and the occurrence of oestrus and to determine the onset and duration of the breeding season of non-pregnant hinds.

\section{Materials and Methods}

\section{Animals and management}

A group of tame (bottle-reared) Père David's deer hinds $(\mathrm{N}=11$; mean liveweight $=177 \cdot 1 \pm 8 \cdot 1 \mathrm{~kg}$ ) was used comprising 43 -year-olds and 72 -year-olds. All animals had undergone at least 1 oestrous cycle before the start of the study and all were nulliparous. There is no published information describing the normal growth and age at puberty in this species. Unless stated otherwise, animals were housed indoors under natural photoperiod $\left(51^{\circ} 30^{\prime} \mathrm{N}\right.$; Whipsnade Park, Bedfordshire, U.K.) and were fed a mixed ration of hay and pelleted lucerne with water supplied ad libitum. Before 13 December 1985, a vasectomized stag was housed with the hinds, but after this date the hinds were maintained in isolation from the stag.

\section{Detection of oestrus}

As indicated below, oestrus was detected with a vasectomized stag which was sedated at 7-10-day intervals so that a mixture of coloured harness chalk and axle grease could be applied to the brisket and abdominal wall in the region of the penis. During the study, hinds were checked twice daily and a distinct coloured mark on the rump was taken as evidence of mating.

In Exp. 2 oestrus was detected by observation of behavioural changes which are very conspicuous in tame hinds. They will actively seek human contact and rub their head against the observer. When pressure is applied to the hindquarters of the animal, it will remain stationary rather than move off quickly as would occur in a non-oestrous animal. During the experimental period behavioural observations were made twice daily.

\section{Collection of blood samples}

Blood samples were collected by jugular venepuncture between 08:30 and 10:00 h. Blood was heparinized, centrifuged and the plasma stored at $-20^{\circ} \mathrm{C}$ until required for assay.

\section{Experimental programme}

Natural oestrous cycles. Between 30 October and 13 December 1985 daily blood samples were collected from 5 hinds. A marked vasectomized stag was used to detect oestrus.

Synchronized oestrous cycles. In Exp. 1, 3 hinds, in which progesterone concentrations had been monitored, were each given an intravaginal sponge containing the progestagen cronolone $(50 \mathrm{mg}$; Chronogest: Intervet, Cambridge, U.K.), inserted during the mid-luteal phase and removed after the decline in endogenous progesterone values (28 October 1985). Animals were sedated with xylazine (25 mg i.m.; Rompun: Bayer U.K., Bury St Edmonds, Suffolk, U.K.) for sponge insertion and again about 15 days later for sponge removal. Blood samples for progesterone determination were taken daily for 50 days from the time of sponge removal. At $32 \mathrm{~h}$ after sponge removal, a marked vasectomized stag was introduced to the group of hinds.

In Exp. 2, 5 hinds were sedated with xylazine and subcutaneous progesterone implants each containing $275 \mathrm{mg}$ progesterone in a silicone-elastomer matrix ( 5 implants per hind; Sil-estrus, Ceva, Paris, France) were inserted in the axilla region under local anaesthesia. The animals were sedated 10 days later ( 8 September 1986), the implants removed and each hind treated with $1.0 \mathrm{ml}$ cloprostenol (Estrumate: Coopers, Crewe, Cheshire, U.K.). For progesterone determinations, blood samples were collected daily for 11 days after sponge removal and thereafter at 2-3-day intervals until 23 days after removal of the implants. On Days 1-5 after sponge removal, each animal was examined twice daily for signs of behavioural oestrus. In Exps I and 2, the progestagen releasing devices were removed between 16:00 and 18:00 h.

Duration of the breeding season. In 1985, termination of the breeding season was monitored in 8 hinds. Blood samples were collected at weekly intervals from 13 December 1985 until 13 June 1986. The location at which the animals were housed was changed on 13 December and from this time the stag was no longer used to detect oestrus. In addition, from 24 December, 5 of the above hinds along with 1 other mature hind were housed individually in pens measuring $2.5 \times 3 \mathrm{~m}$. Above a height of $1 \mathrm{~m}$ the walls of each pen were made of mesh so that each animal had visual contact with adjacent animals. The 3 remaining hinds were maintained at pasture with two pre-pubertal hinds until 13 June after which they were group housed indoors.

The onset of breeding in mid-1986 was examined in 9 hinds from which blood was collected twice weekly between 13 June and 28 July and three times a week thereafter. The end of the breeding season was monitored in 11 hinds with weekly blood samples collected between 1 December 1986 and 27 February 1987. 


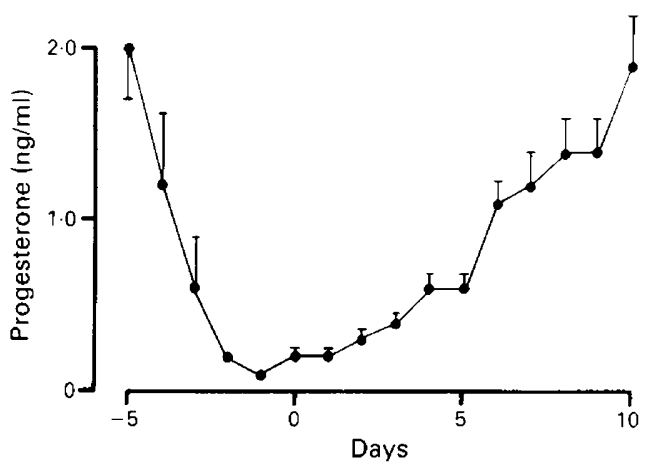

Fig. 1. Mean \pm s.e.m. plasma progesterone concentrations in naturally cycling Père David's deer hinds $(\mathrm{N}=4)$. Profiles are normalized around the day of mating by a marked vasectomized stag. Blood samples were collected daily.

\section{Progesterone radioimmunoassay}

Plasma was extracted with diethyl ether and progesterone concentration measured by radioimmunoassay as previously described (Curlewis et al., 1987) but using antibody HP/S/645-111A (NETRIA, St Bartholomew's Hospital, London, U.K.) which was raised in sheep against progesterone $11 \alpha$-hemisuccinate-BSA conjugate. ${ }^{125}$ I-labelled progesterone was supplied by NETRIA and its preparation has been described elsewhere (Webley \& Edwards, 1985). Progesterone standard (Sigma Chemical Co., St Louis, MO, U.S.A.) was added at concentrations of 3-400 pg/tube. Free and bound ${ }^{125} \mathrm{I}$-labelled progesterone were separated by a second antiserum method using donkey anti-sheep serum. All dilutions were made in $0.1 \mathrm{M}$-sodium phosphate buffer containing $0.1 \%$ gelatin $(\mathrm{w} / \mathrm{v}), \mathrm{pH} 7 \cdot 0$. The antibody bound $40 \%$ of ${ }^{125} \mathrm{I}$-labelled progesterone at a final dilution of $1: 18000$ and $50 \%$ of bound ${ }^{125} \mathrm{I}$-labelled progesterone was displaced by $27 \mathrm{pg}$ progesterone. Sensitivity, defined as the first point on the standard curve significantly different from zero binding, was $3 \mathrm{pg} /$ tube $(0.08 \mathrm{ng} / \mathrm{ml}$ plasma). Cross-reactivities at the $50 \%$ displacement level were as follows: 1 I $\beta$-hydroxyprogesterone, $208.3 \% ; 11 \alpha$-hydroxyprogesterone, $80.6 \% ; 16 \alpha$-hydroxyprogesterone, $9.0 \%$; $5 \alpha$-pregnanedione, $8.3 \%$; $5 \beta$-pregnanedione $3.2 \% ; 20 \alpha$-dihydroprogesterone, $2.4 \% ; 17 \alpha$-hydroxyprogesterone, testosterone and corticosterone, $0.9 \%$; androstenedione, cortisol, oestradiol- $17 \beta$ and $5 \beta$-pregnanediol, $<0.3 \%$. To examine whether compounds other than progesterone cross-reacted in the assay, extracts of plasma $(N=2)$ to which trace amounts of $\left[{ }^{3} \mathrm{H}\right]$ progesterone had been added were processed by celite column chromatography (Abraham $e t$ al., 1973). Hormone concentration in each fraction was measured by radioimmunoassay as described above. Immunoreactive material was found only in those fractions which corresponded to the elution profile of $\left[{ }^{3} \mathrm{H}\right]$ progesterone.

Recovery of $\left[{ }^{3} \mathrm{H}\right]$ progesterone added to plasma was determined for each assay and all samples were corrected for these losses. Mean recovery over 7 assays was $80 \pm 0.6 \%$ ( \pm s.e.m.). Extracts of deer plasma containing high progesterone values were diluted in parallel with the progesterone standard. To assess the accuracy of the assay, progesterone $(1-8 \mathrm{ng} / \mathrm{ml})$ was added to plasma which contained low progesterone and progesterone concentration was measured. Recovery of added progesterone was $83 \pm 3 \%(n=11)$. The intra-assay coefficient of variation measured in plasma samples containing $1.6,3.6$ and $7.9 \mathrm{ng} / \mathrm{ml}$ was $3.3,5.3$ and $2.9 \%$ respectively. The inter-assay coefficient of variation measured in plasma containing 1.6 and $6.3 \mathrm{ng} / \mathrm{ml}$ was 9.5 and $11.6 \%$ respectively. Progesterone could not be detected in extracts of buffer and was not detectable or was present at very low concentrations $(0.2 \pm 0.01 \mathrm{ng} / \mathrm{ml})$ in plasma from 10 anoestrous hinds.

\section{Statistics}

Results were analysed by analysis of variance. Duncan's multiple range test was used to compare progesterone concentrations at oestrus with those at other days of the cycle.

\section{Results}

\section{Natural oestrous cycles}

Oestrous cycle progesterone profiles based on daily samples were obtained from 5 hinds. Mean progesterone concentrations from the 4 mated hinds were normalized around the day of mating and in Fig. 1 the hormone profiles from Days -5 to 10 (Day $0=$ day of oestrus) are shown. There was a 

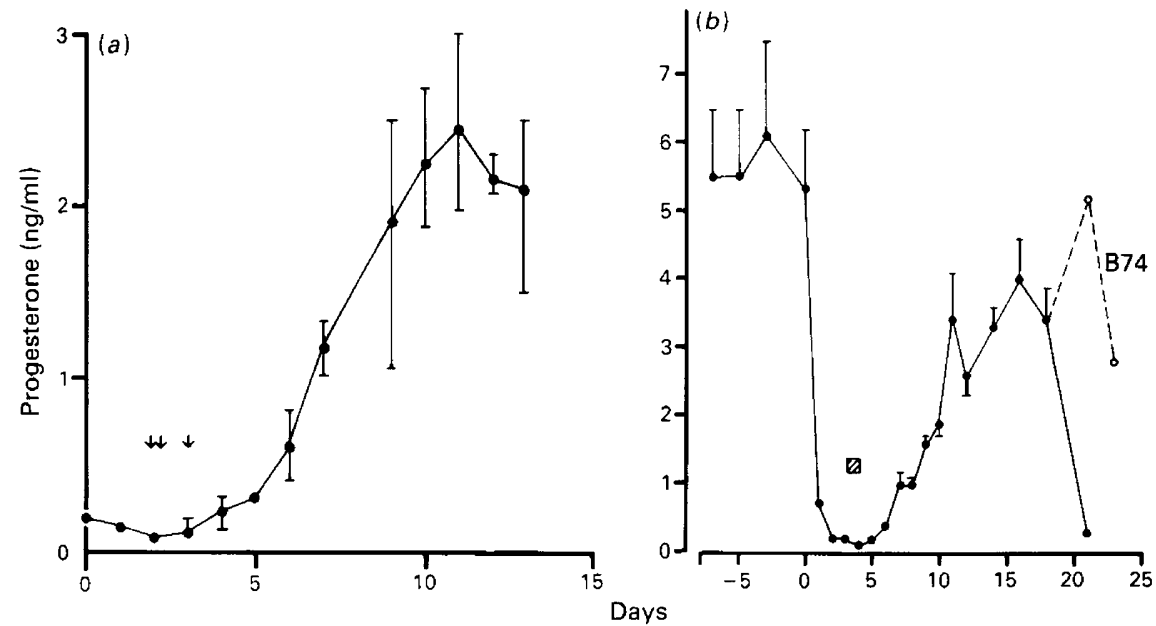

Fig. 2. Plasma progesterone concentrations in Père David's deer hinds which had been treated with exogenous progestagens to synchronize oestrus. (a) Progestagen-impregnated intravaginal sponges were removed from 3 hinds on Day 0. Arrows indicate mating by a marked vasectomized stag. Results are the mean \pm range. (b) Subcutaneous progesterone implants were removed and each animal was injected with cloprostenol on Day 0. Results are the mean \pm s.e.m. for 5 hinds. The hatched area represents times when animals showed behavioural oestrus. Hind B74 returned to oestrus 10 days later than the other animals and therefore the progesterone results for this animal are shown separately after Day 18.

significant $(P<0.01)$ change in progesterone concentration during the cycle. Oestrus was preceded for 2 days by low or non-detectable progesterone concentrations $(0.14 \pm 0.03 \mathrm{ng} / \mathrm{ml}$; mean \pm s.e.m.); by Day 4, progesterone concentrations had increased significantly (Day 0 vs Day 4 , $P<0.05$ ), and thereafter continued to increase. The mean maximum progesterone concentration of $3.5 \pm 0.6 \mathrm{ng} / \mathrm{ml}$ occurred $18 \pm 2.8$ days after oestrus (results not shown) and was followed by a decrease to basal levels.

\section{Synchronized oestrous cycles}

The results of Exps 1 and 2 are shown in Figs 2(a) and 2(b) respectively and are summarized in Table 1. In Exp. 1, oestrus occurred 32-64 h after sponge removal. Progesterone concentrations before removal of the sponges were near the detection limit of the assay and remained low in all animals several days after oestrus. After oestrus there was a significant $(P<0.01)$ increase in progesterone concentrations, with increased values first evident 4 days after oestrus $(P<0.05)$. The mean maximum progesterone concentration of $5 \cdot 1 \pm 2 \cdot 1 \mathrm{ng} / \mathrm{ml}$ occurred $22 \pm 6 \cdot 7$ days after oestrus (results not shown). In Exp. 2, progesterone concentrations before removal of the implants were in excess of $3 \mathrm{ng} / \mathrm{ml}$ in all animals. On the day after implant removal progesterone was still detectable but on the following day, progesterone concentrations were low or not detectable in all animals. The onset of behavioural oestrus occurred $66-90 \mathrm{~h}$ after removal of the implants and was followed by a significant $(P<0.015)$ increase in progesterone concentrations with increased values first evident on day 4 after oestrus (oestrus $v s$ Day 4 after oestrus, $P<0.05$ ). Mean maximum progesterone concentrations of $4.9 \pm 0.3 \mathrm{ng} / \mathrm{ml}$ occurred $12 \pm 0.3$ days after oestrus.

The changes in progesterone concentrations after oestrus are summarized in Table 1. In all cases, an increase in progesterone concentration first occurred 4 days after oestrus. 
Table 1. Summary of results from natural and synchronized oestrous cycles for Père David's deer hinds

\begin{tabular}{|c|c|c|c|c|c|}
\hline & $\begin{array}{l}\text { No. } \\
\text { of deer }\end{array}$ & $\begin{array}{l}\text { Progestagen } \\
\text { removal to } \\
\text { oestrus } \\
\text { (h) }\end{array}$ & $\begin{array}{l}\text { Oestrus to } \\
\text { significant* } \\
\text { increase in } \\
\text { progesterone } \\
\text { conc. } \\
\text { (days) }\end{array}$ & $\begin{array}{l}\text { Oestrus to } \\
\text { progesterone } \\
\text { conc. } \\
>0.5 \mathrm{ng} / \mathrm{ml} \\
\text { (days) }\end{array}$ & $\begin{array}{l}\text { Duration of } \\
\text { elevated } \\
\text { progesterone } \\
(>0.5 \mathrm{ng} / \mathrm{ml} \text { ) } \\
\text { after oestrus } \\
\text { (days) }\end{array}$ \\
\hline $\begin{array}{l}\text { Natural oestrous } \\
\text { cycles }\end{array}$ & 4 & - & 4 & $\begin{array}{c}4 \cdot 3 \pm 0 \cdot 6 \\
(3-6)\end{array}$ & $\begin{array}{l}17 \cdot 0 \pm 2 \cdot 4 \\
(10-20)\end{array}$ \\
\hline $\begin{array}{l}\text { Exp. 1: cronolone } \\
\text { sponges }\end{array}$ & 3 & $\begin{array}{l}42 \pm 10 \\
(32-64)\end{array}$ & 4 & $\begin{array}{c}4 \\
(4)\end{array}$ & $\begin{array}{c}20 \cdot 0 \pm 3 \cdot 2 \\
(12-38)\end{array}$ \\
\hline $\begin{array}{l}\text { Exp. 2: progesterone } \\
\text { implants }(\mathrm{s} / \mathrm{c})\end{array}$ & 5 & $\begin{array}{l}71 \pm 5 \\
(66-90)\end{array}$ & 4 & $\begin{array}{c}3 \cdot 2 \pm 0 \cdot 2 \\
(3-4)\end{array}$ & $\begin{array}{l}12 \cdot 4 \pm 2 \cdot 4 \\
\quad(9-22)\end{array}$ \\
\hline
\end{tabular}

Values are means \pm s.e.m. with the range in parentheses.

*Analysis of variance with Duncans multiple range test, $P<0.05$.

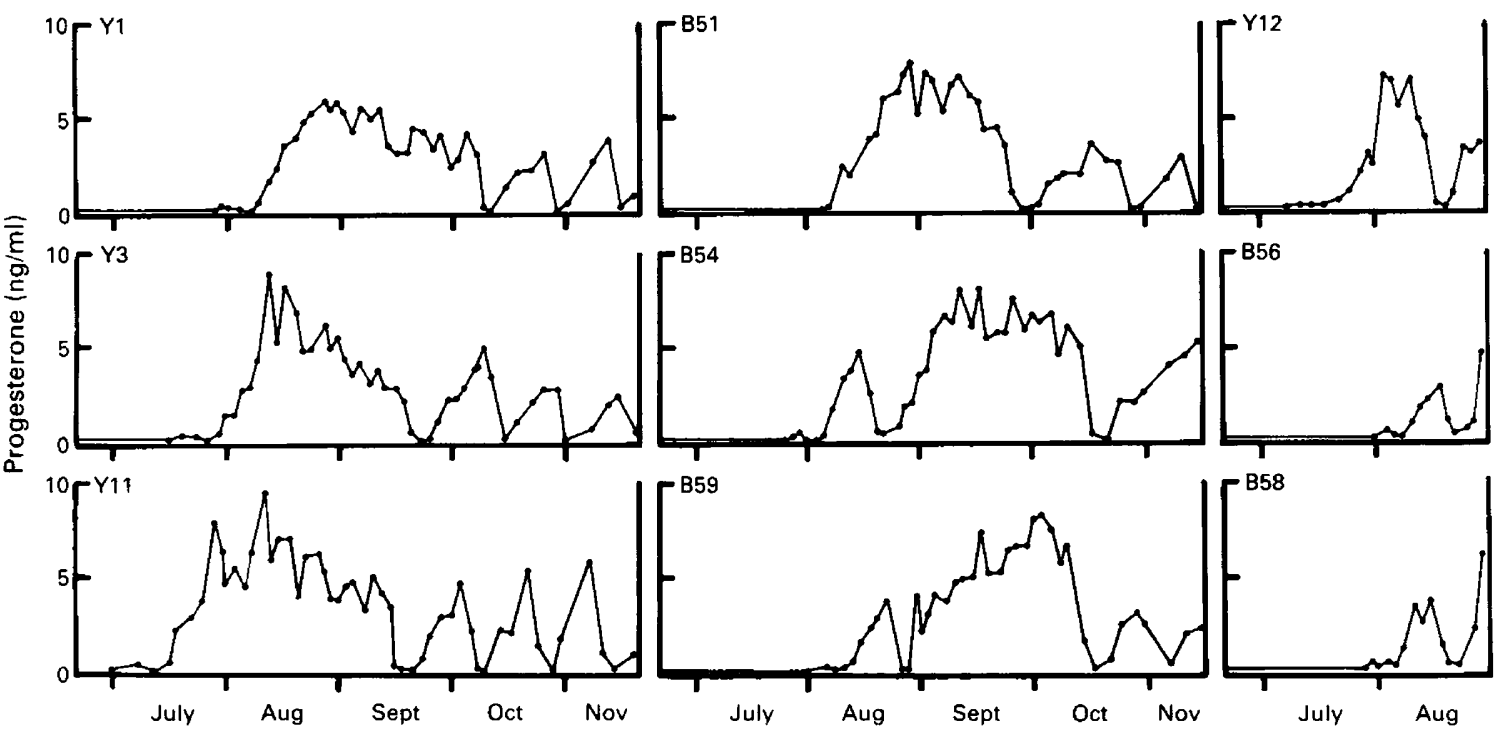

Fig. 3. Plasma progesterone concentrations in individual Père David's deer hinds at the beginning of the breeding season in 1986. Three of the animals (Y12, B56 and B58) were penned indoors together with 2 other hinds; the remaining animals were individually penned.

\section{Duration of the breeding season}

The end of the breeding season for an individual hind was taken as the last date on which progesterone concentrations exceeded $0.5 \mathrm{ng} / \mathrm{ml}$. In 1985 and 1986 , the mean ( \pm s.e.m.) dates for the termination of the breeding season were 18 December $( \pm 5 \cdot 7$ days; $N=8)$ and 6 January $( \pm 3 \cdot 2$ days; $\mathrm{N}=11$ ) respectively. The onset of breeding in mid-1986 was taken as the date on which progesterone concentrations first exceeded $0.5 \mathrm{ng} / \mathrm{ml}$ and remained above that concentration for at least 7 days. The mean ( \pm s.e.m.) date for the onset of the breeding season was 2 August $( \pm 3.3$ days; $N=9)$. Figure 3 shows the progesterone profiles of individual hinds at the beginning of the breeding season in 1986. During a 10-day period before the first luteal phase, all except 1 animal (B 51) 
showed an increase in mean progesterone concentrations from anoestrous levels $(<0 \cdot 2 \mathrm{ng} / \mathrm{ml})$ to $0.5 \pm 0.05 \mathrm{ng} / \mathrm{ml}$. In 6 animals, progesterone concentrations then returned to anoestrous levels before again increasing.

\section{Oestrous cycle length}

In experiments in which the vasectomized stag was used to detect oestrus (natural oestrous cycles and Exp. 1), marking of hinds by the stag was not always observed at consecutive periods of low progesterone concentrations. Therefore, the length of the oestrous cycle could not be estimated by calculating the interval between matings. So that comparisons could be made between natural and synchronized cycles, the time that progesterone values were in excess of $0.5 \mathrm{ng} / \mathrm{ml}$ was calculated. These results (Table 1) show that the duration of elevated progesterone concentrations varied greatly between animals ranging from 9 to 38 days but there appeared to be no effect of treatment on cycle length. An estimate of oestrous cycle length was derived from the animals used in Exp. 2 in which behavioural observations were made from the start of the experiment on 8 September until 14 December: 19 oestrous cycles were recorded with each hind showing 3-5 consecutive cycles, and the mean duration of the oestrous cycles was $19.5 \pm 0.6$ days.

Further information about the length of the oestrous cycle comes from the progesterone profiles obtained from 9 hinds at the beginning of the breeding season in 1986 (Fig. 3). In the first luteal phase of the breeding season, 4 of the individually penned animals (Y1, Y3, Y11 and B51) showed elevated progesterone concentrations for periods ranging from 45 to 60 days. The 2 remaining hinds (B54 and B59) and the 3 group-housed animals (Y12, B56 and B58) showed a much shorter duration of increased progesterone in their first cycle of the breeding season (range 10-20 days) but the 2 individually housed animals (B54 and B59) showed a prolonged duration (50 and 45 days respectively) of increased progesterone in their second cycle.

\section{Discussion}

The results of the present study demonstrate that the Père David's deer hind is seasonally polyoestrous with cycles starting at the end of July or early August and terminating in December or January. Plasma progesterone concentrations during the breeding season and in anoestrus were similar to those reported for other seasonally polyoestrous ungulates such as the ewe (Walton et al., 1977; Quirke et al., 1979), goat (Jones \& Knifton, 1972; Thorburn \& Schneider, 1972) and red (Adam et al., 1985) and fallow (Asher, 1985) deer hinds. When intravaginal or subcutaneous progestagenreleasing devices were used to synchronize oestrus during the breeding season, oestrus occurred $32-90 \mathrm{~h}$ after progestagen removal. Although the animals treated with the progestagen-impregnated sponges showed oestrus earlier than those treated with subcutaneous progesterone implants $(43 \pm 10 \cdot 7 \mathrm{~h}$ and $71 \pm 4 \cdot 8 \mathrm{~h}$ respectively), the vastly different experimental procedures in each study preclude a direct comparison.

The wide variation in the duration of elevated progesterone concentrations observed here in the Père David's deer hind appears to be an unusual finding in a species of ungulate. In the present study, cycle length based on the observation of behavioural oestrus was 19.5 days ( 19 cycles from 5 hinds; Exp. 2). In these hinds, the mean \pm s.e.m. lengths of the first luteal phase and oestrous cycle after progesterone removal were $12 \pm 2.4$ and $20 \pm 1.9$ days respectively. From the progesterone profiles obtained from these and other hinds elsewhere in this study, it is clear that cycles of similar length occurred frequently (cycles less than 30 days; mean \pm s.e.m. length of the luteal phase was $12.6 \pm 0.9$ days; $n=23$ ). However, luteal phases of much longer duration were also observed (cycles greater than 30 days; luteal phase length was $49 \cdot 3 \pm 2 \cdot 8 ; n=7$ ) and it is possible that these long cycles may represent a persistent corpus luteum. Red deer hinds may also show variation in oestrous cycle length. Guinness et al. (1971) reported that the cycle length in hinds which were mated by a marked vasectomized stag was about 18 days. However, these authors excluded 9 long cycles (range 34-59 
days) from their estimate of the mean, suggesting that the prolonged interval between matings may have resulted from failure of the vasectomized stag to detect oestrus. Adam et al. (1985) monitored progesterone concentrations in hinds which were in the presence of a stag and reported that the cycle length in 4 red deer hinds was 21 days but the fifth animal showed a cycle of 35 days. In this case a termination of pregnancy and return to oestrus cannot be discounted. More detailed information is available for the fallow deer hind in which cycle length and degree of variation increase as the breeding season proceeds; however in 142 observations cycle length did not exceed 27 days (Asher, 1985). Therefore, it appears that the hinds of several deer species are similar in that the average length of the oestrous cycle is around 20 days but considerably longer cycles may occur in the red deer and are not infrequent in Père David's deer. In the present study, the conditions under which hinds were maintained was not kept constant and it remains to be determined whether animals kept in a herd along with a stag would show the same variation in cycle length.

At the beginning of the breeding season progesterone concentrations in 8 of the 9 hinds increased from anoestrous levels to around $0.4 \mathrm{ng} / \mathrm{ml}$ for several days in the 2 weeks preceding the first cycle. Although Guinness et al. (1971) have claimed that silent ovulations before the first oestrus of the breeding season do not occur in the red deer hind, the phenomenon has been described in other seasonal ungulates (sheep: Walton et al., 1977; fallow deer: Asher, 1985). In the ewe it has been shown that progesterone priming is essential to ensure normal luteal function at the subsequent ovulation (McLeod et al., 1982; McLeod \& Haresign, 1984). In addition, Legan et al. (1985) have shown that some of the priming effects of progesterone require only low physiological concentrations of progesterone for as little as 3 days. Therefore it is possible that the transient increase in progesterone measured before the first cycle in the Père David's deer hind may serve a similar function to that reported for the ewe.

In the semi-captive population of the Père David's deer at Whipsnade Park, the majority of calves are born in April (Kirkwood et al., 1987). Based on a gestation length of 282 days (Wemmer, 1983) most hinds would therefore conceive before $22 \mathrm{July}$. This corresponds well with the occurrence of rutting behaviour in the same herd which commences in May and is most intense during the month of June. In the present study, the mean date of the first oestrous cycle of the breeding season was 2 August and only 2 hinds had shown evidence of a reproductive cycle by $22 \mathrm{July}$. So although it is likely that the timing of reproduction in this species is ultimately controlled by photoperiod, it is tempting to speculate that factors such as behavioural effects, pheromones or environment (e.g. temperature, nutrition) may affect the breeding season of this species and account for the late onset of breeding in the study group.

We thank Alison Beasey and Barrie Eves for technical assistance and maintenance of the experimental animals during the various stages of this study; Intervet, Cambridge, for the gift of cronolone sponges; and Dr B. McLeod for comments on the manuscript. This study was supported in part by a project grant from the A.F.R.C.

\section{References}

Abraham, G.E., Buster, J.E., Kyle, F.W., Corrales, P.C. \& Teller, R.C. (1973) Radioimmunoassay of plasma pregnenolone. J. clin. Endocr. Metab. 37, 40-45.

Adam, C.L., Moir, C.E. \& Atkinson, T. (1985) Plasma concentrations of progesterone in female red deer (Cervus elaphus) during the breeding season, pregnancy and anoestrus. J. Reprod. Fert. 74, 631-636.

Asher, G.W. (1985) Oestrous cycle and breeding season of farmed fallow deer, Dama dama. J. Reprod. Fert. 75, 521-529.
Curlewis, J.D., White, A.S. \& Loudon, A.S.I. (1987) The onset of seasonal quiescence in the female Bennett's wallaby (Macropus rufogriseus rufogriseus). J. Reprod. Fert. 80, 119-124.

Guinness, F.E., Lincoln, G.A. \& Short, R.V. (1971) The reproductive cycle of the female red deer, Cervus elaphus L. J. Reprod. Fert. 27, 427-438.

Jones, D.E. \& Knifton, A. (1972) Progesterone concentrations in the peripheral plasma of goats during the oestrous cycle. Res. Vet. Sci. 13, 193-195. 
Kirkwood, J.K., Gaskin, C.D. \& Markham, J. (1987) Perinatal mortality and birth season in captive wild ungulates. Vet. Rec. 120, 386-390.

Legan, S.J., I'Anson, H., Fitzgerald, B.P. \& Akaydin, M.S. (1985) Importance of short luteal phases in the endocrine mechanism controlling initiation of estrous cycles in anestrous ewes. Endocrinology 117, $1530-1536$.

McLeod, B.J. \& Haresign, W. (1984) Evidence that progesterone may influence subsequent luteal function in the ewe by modulating preovulatory follicle development. J. Reprod. Fert. 71, 381-386.

McLeod, B.J., Haresign, W. \& Lamming, G.E. (1982) Response of seasonally anoestrous ewes to small-dose multiple injections of Gn-RH with and without progesterone pretreatment. J. Reprod. Fert. 65, 223-230.

Quirke, J.F., Hanrahan, J.P. \& Gosling, J.P. (1979) Plasma progesterone levels throughout the oestrous cycle and release of $\mathrm{LH}$ at oestrus in sheep with different ovulation rates. J. Reprod. Fert. 55, 37-44.

Thorburn, G.D. \& Schneider, W. (1972) The progesterone concentration in the plasma of the goat during the oestrous cycle and pregnancy. J. Endocr. 52, 23-36.

Walton, J.S., McNeilly, J.R., McNeilly, A.S. \& Cunningham, F.J. (1977) Changes in concentration of follicle-stimulating hormone, prolactin and progesterone in the plasma of ewes during the transition from anoestrous to breeding activity. J. Endocr. 75, 127-131.

Webley, G.E. \& Edwards R. (1985) Direct assay for progesterone in saliva: comparison with a direct serum assay. Ann. Clin. Biochem. 22, 579-585.

Wemmer, C.W. (1983) Sociology and management. In The Biology and Management of an Extinct Species, Père David's Deer, pp. 126-132. Eds B. B. Beck \& C. W. Wemmer. Noyes Publications, New Jersey.

Received 25 March 1987 